\title{
MEMAKNAI KEMBALI PENINGKATAN PROFESIONALISME TENAGA PENDIDIK PENDIDIKAN NONFORMAL
}

\author{
S. Wisni Septiarti \& Mulyadi
}

\begin{abstract}
Professionalism of the non-formal education personnel, which is understood as competency development, is a necessity. If we see from various points of view particularly from sociocultural aspects, the study on the dynamics of non-formal education personnel's profession, becomes the essential part of this articel. The flexibility, which tends to be biased over time, age, materials or presentation approaches and sosiocultural aspects within the process of learning, becomes the reference for the personnel's quality improvement efforts. Even though, in common public point of view, the existence of formal teachers is stronger than non-formal education personnel, but the NFE program development in reality is largely required. This happens because many people have not been served by the formal education system. In order to re-defined the meaning of professionalism of the NFE as an effort of the education quality improvement normatively, there is a necessity to improve the culture of operation and the dialogues among education personnel up to the education managers.
\end{abstract}

Key words: non-formal education, non-formal education personnel, sosioculture.

\section{PENDAHULUAN}

Ketika pendidikan dipandang sebagai salah satu tolok ukur untuk melihat kualitas kehidupan sebuah bangsa, pengembangan sumber daya manusia baik secara kualitas maupun kuantitas bukanlah serangkaian slogan semata melainkan usaha yang terus menerus diupayakan. Tanpa memiliki sumber daya yang berkualitas akan sulit mencapai masyarakat dengan daya saing tinggi terhadap bangsa lain yang sudah maju. Salah satu tolok ukur yang digunakan adalah tingkat keterbacaan (literacy).

Dalam laporan yang bertajuk Human Development Report 2004, UNDP (sebuah badan PBB) melaporkan bahwa angka buta huruf dewasa (adult illiteracy) di Indonesia mencapai 12,1\%. Ini berarti dari setiap 100 orang Indonesia dewasa yang berusia 15 tahun ke atas, ada 12 orang yang tidak dapat membaca. Angka ini relatif jauh lebih tinggi, apabila kita bandingkan dengan negara-negara lain, seperti Thailand $(7,4 \%)$, Brunei Darussalam $(6,1 \%)$, dan Jepang $(0,0 \%)$. Pada tahun yang sama (2004), UNDP juga mengeluarkan laporannya tentang kondisi HDI (Human Develeopment Index) di Indonesia. HDI Indonesia berada pada urutan ke 111 dari 175 negara. Posisi ini masih jauh dari negara-negera tetangga seperti Malaysia yang menempati urutan ke-59, Thailand

\footnotetext{
* Dosen Jurusan PLS FIP UNY
}

menempati urutan ke-76, dan Philipina pada urutan ke83.

Tahun 2007, Pemerintah dalam kebijakan operasionalnya sudah mengalokasikan $20 \%$ dari APBN untuk sektor pendidikan, namun karena kondisi keuangan Negara, realisasi akan dicapai dalam beberapa tahap. Dalam tahun anggaran 2004 yang lalu, untuk sektor pendidikan baru dialokasikan sebesar $6,6 \%$, tahun 2005 telah meningkat $9,29 \%$, dan tahun 2006 dialokasikan $12,1 \%$, sebesar $14,60 \%$ untuk anggaran tahun 2007 dan berturut-turut sampai tahun 2009 nanti, diharapkan anggaran untuk sektor pendidikan akan mencapai $17,40 \%$ dan $20,10 \%$. Keadaan seperti itu juga dipengaruhi antara lain oleh berbagai peristiwa termasuk di dalamnya bencana alam serta masalah-masalah sosial lain yang juga memerlukan perhatian tersendiri. Salah satu contoh masalah sosial sebagai akibat rendahnya kualitas pendidikan adalah meningkatnya tingkat pengangguran. Berdasarkan data sakernas, BPS tahun 2004 menunjukkan bahwa dari total angkatan kerja 103,97 juta orang, yang menganggur sebanyak 10,25 juta orang dengan tingkat pendidikan mulai dari tidak pernah sekolah hingga lulusan universitas.

Berkaitan dengan permasalahan tersebut di atas, Departemen Pendidikan Nasional menggulirkan sejumlah program reformasi yang tercakup dalam tiga pilar besar, yaitu perluasan dan pemerataan akses, peningkatan mutu dan relevansi, dan good 
governance dan pencitraan publik. Apabila ketiga pilar tersebut dilaksanakan secara konsekuen di semua lini dan jenjang pendidikan baik pendidikan formal maupun nonformal, Indonesia akhirnya akan diperhitungkan dalam percaturan global. Hal ini dikarenakan jati diri suatu bangsa sangat ditentukan oleh kualitas manusia yang berpendidikan (educated) dan berbudaya (civilized) (Tilaar, 1999; Fasli Jalal, 2001).

Secara umum, mencerdaskan kehidupan bangsa bukan hanya tugas pendidikan formal saja, akan tetapi pendidikan nonformal memiliki peran dan fungsi yang strategis sesuai amanat UU No. 20 Tahun 2003 tentang Sistem Pendidikan Nasional, pasal 26, yang menyatakan bahwa pendidikan nonformal diselenggarakan bagi warga masyarakat yang memerlukan layanan pendidikan yang berfungsi sebagai pengganti, penambah, dan/atau pelengkap pendidikan formal dalam rangka mendukung pendidikan sepanjang hayat. Selanjutnya, pendidikan nonformal menurut Suryadi (2007) melalui kebijakan pembangunan pendidikan nonformal disebutkan sebagai program yang dapat mengatasi kegagalan pendidikan formal pada masa lalu, masa sekarang, masa datang, dan setiap masa. Artinya, kehadiran pendidikan nonformal di masyarakat membantu masyarakat bangkit dari berbagai keterpurukan, kebodohan, ketertinggalan dan kemiskinan. Melihat fenomena tersebut, peningkatan profesionalisme tenaga pendidik dan kependidikan nonformal merupakan sebuah keniscayaan dalam mencapai pendidikan yang berkualitas atau pendidikan untuk semua (education for all). Yang menjadi persoalan adalah bagaimana tugas yang begitu besar dan kompleks dalam zona pendidikan nonformal ini dapat diselenggarakan melalui pusat-pusat kegiatan belajar yang ada di masyarakat, sementara tenaga pendidik dan kependidikannya masih memiliki banyak kelemahan baik dilihat dari kompetensi, jumlah, maupun komitmen lain yang berkaitan dengan kebutuhan belajar masyarakat. Melalui tulisan ini, profesionalisme tenaga pendidik nonformal kembali dimaknai dalam tugasnya sebagai pelaksana, pemotivasi warga belajar hingga pembimbingan dan penilaian hasil belajar. Pemaknaan kembali atas profesionalisme tenaga pendidik pendidikan nonformal yang kompeten di bidangnya juga memiliki penguasaan atas hakikat masyarakat dan hakikat manusia. Selain itu, memaknai profesionalisme tenaga pendidik tidak lepas dari pengaruh dan permasalahan dalam konteks sosiokultural masyarakat sehingga dapat digunakan sebagai masukan bagaimana peningkatan mutu tenaga pendidik pendidikan nonformal dilakukan oleh para pengambil keputusan.

\section{PEMBAHASAN}

\section{Profesionalisme dan Peningkatan Mutu Tenaga Pendidik Nonformal}

Melalui berbagai kesempatan seminar, lokakarya, tulisan, serta pencanangan strategi dan kebijakan Departemen Pendidikan Nasional melalui Direktorat Peningkatan Mutu Pendidik dan Tenaga Kependidikan - Pendidikan Nonformal (PM PTK-PNF) serta Direktorat Pendidikan Nonformal dan Informal dengan jelas dan terarah telah diketengahkan mengenai strategi dan kebijakan pemerintah termasuk di dalamnya upaya peningkatan mutu pendidik pendidikan nonformal.

Pendidikan nonformal berfungsi mengembangkan potensi warga belajar dengan penekanan pada penguasaan pengetahuan dan keterampilan fungsional serta pengembangan sikap dan kepribadian profesional. Pendidikan nonformal meliputi pendidikan kecakapan hidup, pendidikan anak usia dini, pendidikan kepemudaan, pendidikan pemberdayaan perempuan, pendidikan keaksaraan, pendidikan keterampilan dan pelatihan kerja, pendidikan kesetaraan, serta pendidikan lain yang ditujukan untuk mengembangkan kemampuan warga belajar. Mutu pendidikan secara signifikan dipengaruhi oleh kualitas masukan, diantaranya adalah warga belajar, pendidik dan tenaga kependidikan. Data BPS tahun 2004 menunjukkan bahwa angka partisipasi sekolah (APS) penduduk usia 7-12 tahun telah mencapai $96,8 \%$ dan usia 13-15 tahun mencapai 83,5\%. Hal tersebut menunjukkan masih terdapat sekitar 3,2\% anak usia 7-12 tahun dan sekitar $16,5 \%$ anak usia 13-15 tahun yang tidak bersekolah, baik karena belum pernah sekolah, putus sekolah, atau tidak melanjutkan ke jenjang yang lebih tinggi. Lebih lanjut diketahui bahwa sebagian besar (76\%) keluarga menyatakan penyebab utama anak putus sekolah atau tidak melanjutkan sekolah adalah karena alasan ekonomi, yang bervariasi dari tidak memiliki biaya sekolah $(67,0 \%)$ serta harus bekerja dan mencari nafkah $(8,7 \%)$.

Konsekuensi atas perluasan dan pemerataan kesempatan belajar pada jenjang pendidikan dasar, sebagai dampak Program wajib belajar (wajar) Pendidikan Dasar 9 Tahun, mengakibatkan semakin bertambahnya partisipasi pada pendidikan menengah. Sampai dengan tahun 2004, APS penduduk usia 1618 tahun sudah mencapai 53,5\%. Meningkatnya 
partisipasi pendidikan menengah tersebut juga akan menimbulkan tekanan pada penyediaan kesempatan belajar. Perluasan dan pemerataan pendidikan juga memberi tuntutan pada peningkatan pemerataan memperoleh pendidikan bagi siswa lulusan SD/MI yang karena kendala tertentu tidak dapat mengikuti pendidikan SMP/MTs reguler, disediakan pendidikan alternatif antara lain melalui program kesetaraan (kejar paket B) atau SMP Terbuka. Di samping itu, peningkatan pemerataan dan perluasan pendidikan dapat ditempuh dengan memberikan pelayanan pendidikan secara khusus, dengan menggunakan pendekatan kontekstual kepada warga belajar yang memiliki karakteristik khusus.

Pada tahun 2007, Depdiknas menetapkan program prioritas, yakni penuntasan wajib belajar 9 tahun dan penuntasan buta aksara. Dengan demikian guna mewujudkan capaian target sasaran, diperlukan pendidik dan tenaga kependidikan (PTK) yang tidak hanya pada jalur formal, namun juga PTK pada jalur nonformal. Kondisi PTK-PNF selama ini masih sangat membutuhkan dukungan pembinaan dari Pemerintah Pusat maupun Daerah sehingga PTK-PNF dapat juga untuk membantu percepatan penuntasan wajar dikdas dan penuntasan buta aksara. Di samping itu program pendidikan kesetaraan dapat dilaksanakan di berbagai tempat yang sudah ada, baik milik pemerintah, masyarakat maupun pribadi, seperti gedung sekolah, Pusat

Profesionalisme bagi
tenaga pendidik pendidikan
formal maupun nonformal
merupakan sebuah kebutuhan
yang tidak dapat ditunda-tunda,
seiring dengan semakin
meningkatnya persaingan dan
tuntutan yang semakin
kompleks.

penghargaan yang diterimanya dipandang belum memadai.

Menurut data yang diperoleh Ditjen PMPTK tahun 2007, terdapat sekitar satu juta pendidik dan tenaga kependidikan nonformal, jumlah yang tidak sedikit. Mereka terdiri tutor keaksaraan, tutor kesetaraan, pamong belajar, tenaga lapangan pendidikan masyarakat, instruktur, penilik pendidikan luar sekolah, pendidik pendidikan anak usia dini, dan lain-lain. Para pendidik dan tenaga kependidikan nonformal ini tersebar di seluruh lembaga-lembaga pendidikan nonformal baik di perkotaan maupun di pedesaan. Sampai dengan tahun 2006 mereka berhadapan dengan sekitar 12,7 juta orang penduduk usia di atas 15 tahun buta aksara, ratusan ribu anak putus sekolah, jutaan anak usia dini belum mencicipi pendidikan, dan jutaan pemuda usia produktif tak memiliki keterampilan. Apabila kelompok tersebut dibiarkan tidak tersentuh oleh kehadiran tenaga pendidik dan kependidikan nonformal yang bermutu, akan bertambah deretan panjang sumber daya manusia Indonesia yang bermutu rendah dan pada saatnya akan menjadikan Indonesia semakin terpuruk dalam percaturan global.

Berbagai program telah dan akan terus dikembangkan oleh Ditjen PMPTK agar kualitas PTK-PNF memiliki kompetensi dalam pelaksanaan tugasnya. Salah satu upaya yang dikembangkan Ditjen PTK-PNF adalah mengenai standarisasi Kegiatan Belajar Masyarakat (PKBM), rumah ibadah, pusat-pusat majelis taklim, balai desa, kantor organisasi-organisasi kemasyarakatan, rumah penduduk dan tempat-tempat lain yang layak juga sangat membutuhkan layanan tenaga pendidik dan kependidikan.

Hal ini menunjukkan betapa Direktorat Pendidik dan Tenaga Kependidikan Pendidikan Nonformal memiliki tugas yang sangat berat. Belum lagi ditambah permohonan para tenaga pendidik nonformal melalui berbagai kesempatan semacam seminar-seminar nasional untuk diperhatikan tingkat kesejahteraan, statusnya (sebagai PNS) bahkan kualitas dan kuantitasnya. Barangkali harapan para tenaga pendidik PNF tidaklah berlebihan mengingat tugas yang diembannya pun sangat berat yakni sebagai pelaksana sekaligus pendidik, pemotivasi warga belajar, penilaian proses dan hasil hingga pembimbing sementara kompetensi dan sertifikasi bagi pendidik dan tenaga kependidikan nonformal sebagaimana yang tercakup dalam PP Nomor 19 tahun 2005. Standar kompetensi pendidik dan tenaga kependidikan yang telah dirumuskan di dalamnya meliputi empat komponen, yaitu: 1) kompetensi pedagogi dan andragogi, 2) kompetensi kepribadian, 3) kompetensi sosial, dan 4) kompetensi profesional. Keempat kompetensi ini secara keseluruhan perlu dimiliki oleh setiap pendidik dan tenaga kependidikan dalam menempatkan diri pada saat pembelajaran berlangsung maupun ketika relasi sosial terjadi di luar pembelajaran. Melalui Rencana Strategis Dit. PTK-PNF ditegaskan bahwa berlangsung dan tidaknya, berhasil dan tidaknya serta bermakna dan tidaknya program pendidikan nonformal sangat bergantung pada potensi, kinerja, mungkin juga dedikasi pendidik yang didukung tenaga kependidikan nonformal. Masing-masing komponen memiliki fungsi dan tugas 
yang saling mendukung secara sinergis agar layanan pendidikan bagi masyarakat terlaksana sesuai harapan semua pihak. Oleh karena itu, profesionalisme para pendidik dan tenaga kependidikan menjadi sangat diperlukan,hingga muncul visi PTK-PNF dalam rencana strategisnya yaitu PTK-PNF Yang Bermutu Tahun 2010.

Profesionalisme bagi tenaga pendidik pendidikan formal maupun nonformal merupakan sebuah kebutuhan yang tidak dapat ditunda-tunda, seiring dengan semakin meningkatnya persaingan dan tuntutan yang semakin kompleks. Sebagai profesi, pengembangan kompetensi tenaga pendidik pada pendidikan formal (guru) serta tenaga pendidik dan tenaga kependidikan PNF yang sering disebut pamong, tutor, atau instruktur merupakan sebuah keharusan dalam kerangka perbaikan kualitas hidup manusia. Profesionalisme bagi tenaga pendidik PNF menuntut keseriusan dalam menghayati kompetensi-kompetensinya juga sehingga seseorang dianggap layak melaksanakan sebuah tugas. Namun demikian semua kompetensi yang dikuasai seorang tenaga pendidik dalam membelajarkan masyarakat tak lepas dari pengaruh dan permasalahan sosiokultural masyarakat yang begitu beragam.

\section{Pengaruh Sosiokultural terhadap Peningkatan Mutu Tenaga Pendidik PNF}

Meningkatkan kompetensi tenaga pendidik PNF pada satuan pendidikan nonformal seperti: lembaga kursus, lembaga pelatihan, kelompok belajar, pusat kegiatan belajar masyarakat, dan majelis taklim, serta satuan pendidikan yang sejenis menjadi tugas dan prioritas pembangunan pendidikan nonformal. Sebagaimana pengertian pendidik dan tenaga kependidikan nonformal oleh Ditjen PTK PNF, pendidik pada pendidikan nonformal dimaknai sebagai anggota masyarakat yang memiliki tugas dan diberikan kewenangan dalam merencanakan dan melaksanakan proses pembelajaran, menilai hasil pembelajaran, melakukan pembimbingan dan pelatihan. Adapun tenaga kependidikan pendidikan nonformal adalah anggota masyarakat yang mengabdikan diri dan diangkat untuk menunjang penyelenggaraan pendidikan nonformal dan bertugas melaksanakan administrasi pengelolaan, pengawasan dan pelayanan teknis untuk menunjang proses pendidikan pada suatu pendidikan nonformal. Peningkatan mutu pendidik dan tenaga kependidikan pendidikan nonformal dimaksudkan sebagai pemenuhan standar kualifikasi dan kompetensi sehingga dapat melaksanakan tugas pokoknya secara optimal. Karena optimalisasi tugas masing-masing tenaga pendidik PNF tidak lepas dari pengaruh sosiokultural masyarakat yang begitu beragam, upaya peningkatan mutu tenaga pendidik PNF bukanlah hal yang mudah.

Kebijakan pembangunan pendidikan nonformal hingga tahun 2010 dititikberatkan kepada programprogram strategis misalnya pelaksanaan gerakan nasional pemberantasan buta aksara, perluasan layanan PAUD, perluasan paket A dan Paket B sebagai penunjang wajar 9 tahun, eksistensifikasi paket $C$, perluasan pendidikan berkelanjutan, kursus dan pendidikan keterampilan yang berorientasi pada kebutuhan masyarakat akan kecakapan hidup, pendidikan perempuan dan pengarusutamaan gender. Program-program PNF tidak dibatasi oleh jenjang, orientasi belajarnya bersifat praktis, fleksibel dan jangka pendek. Program pembelajaran merupakan respon dari kebutuhan mendesak dari masyarakat dan tidak berorientasi pada ijazah. Dalam proses belajarnya, pendidikan nonformal lebih menekankan pada beberapa prinsip seperti : menempatkan warga belajar sebagai subyek yang aktif, menekankan pada kebutuhan warga belajar, menggunakan pendekatan partisipatif sejak persiapan/perencanaan program belajar, pelaksanaan program pembelajaran sampai dengan evaluasi kemajuan belajarnya.

Mengingat kehadiran pendidikan nonformal dalam ikut mencerdaskan bangsa sangat diperlukan, peningkatan mutu pendidik dan tenaga kependidikan nonformal adalah sebagai keharusan karena terkait pula dengan konsep dasar pendidikan sepanjang hayat. Beberapa hal yang masih menjadi permasalahan berkaitan dengan peningkatan profesionalisme pendidik dan tenaga kependidikan pendidikan nonformal ini adalah sebagai berikut.

1. Belum optimalnya peran pendidik dan tenaga kependidikan nonformal dalam memenuhi kebutuhan belajar masyarakat.

2. Ketidaksesuaian kompetensi pendidik dan tenaga kependidikan pendidikan nonformal dengan bidang garapan yang menjadi tugasnya.

3. Menjadi pendidik dan tenaga kependidikan masih sebatas sampingan.

4. Tidak meratanya kehadiran pendidik dan tenaga kependidikan di desa dan kota.

5. Belum seluruh masyarakat memahami keberadaan pendidikan nonformal.

Sebagai bagian peningkatan profesionalisme (pengembangan kompetensi) pendidik dan tenaga kependidikan pendidikan nonformal, analisis kebutuhan, pemetaan, dan sumber penyedia menjadi awal upaya memaknai kembali kehadiran PTK-PNF di tengahtengah masyarakat. Hal tersebut dilakukan berkaitan 
dengan begitu beragamnya permasalahan yang dihadapi dalam mendukung penuntasan wajar Dikdas 9 tahun dan pemberantasan buta aksara. Pemetaan mutu PTK-PNF dalam tahun 2006, telah diupayakan oleh Direktorat PTK-PNF, minimal diperolehnya data dan informasi tentang keadaan PTK-PNF. Sumber penyediaan bagi Tutor Kesetaraan dan Tutor Keaksaraan belum sepenuhnya dapat terlayani dengan memadai. Pandangan masyarakat terhadap eksistensi pendidik dan tenaga kependidikan nonformal tidak sekuat bila dibandingkan pandangan mereka terhadap pendidik dan tenaga kependidikan pendidikan formal sehingga memaknai dan meningkatkan profesionalisme dan mutu pendidik dan tenaga kependidikan nonformal ini bukanlah sesuatu yang mudah untuk dilakukan

Analisis kebutuhan pelatihan bagi Tutor Kesetaraan dan Tutor Keaksaraan sebagai salah satu dasar pertimbangan suatu penyelenggaraan pelatihan yang berkualitas perlu dilakukan. Untuk itu, diperlukan kegiatan yang cermat pada saat perencanaan pelatihan. Pada saat ini, masih ditemui beberapa hambatan menjangkau kebutuhan pelatihan, misalnya apakah ada perbedaan yang signifikan antara kebutuhan belajar tutor yang berada di pedesaan dan perkotaan, bagaimana strategi pelatihan diterapkan bagi tutor yang berasal jauh dari jangkauan kegiatan pelatihan.

Upaya untuk mendukung unjuk kerja/kinerja pendidik pendidikan nonformal sangat diperlukan dukungan kualifikasi dan kompetensi yang dimiliki pendidik. Dari catatan Ditjen PTK-PNF saat ini, secara keseluruhan kualifikasi tutor yang telah $\mathrm{S} 1$ baru mencapai $60 \%$, sedangkan kompetensi mengajar dan penguasaan bahan ajar masih belum memadai dibandingkan dengan tujuan pembelajaran yang diharapkan dari kegiatan Paket A dan B. Misalnya, seorang tutor harus memiliki kemampuan dalam membelajarkan warga belajar yang pada umumnya memiliki keterbatasan waktu dan ekonomi sehingga pembelajaran tetap menyenangkan baginya. Begitu pun halnya dengan tutur keaksaraan, seringkali ditemui kegiatan pembelajaran yang dikelola tutor masih konvensional, kurang merangsang aktivitas belajar bagi warga belajarnya. Oleh karena itu, dalam pengembangan kompetensi bagi para tutor seringkali dilakukan variasi pembelajaran secara tematik, kontekstual sebagaimana dipahami dan disesuaikan dengan kemauan dan kemampuan warga belajar.

Di sisi lain, karakteristik warga belajar yang berbeda dengan siswa di persekolahan, tentunya membutuhkan pendekatan dan strategi yang sesuai dengan karakteristik dari warga belajar. Salah satunya, tutor harus memiliki kemampauan mengkaitkan keterampilan fungsional dengan kegiatan pembelajaran keaksaraan. Aspek penyajian keterampilan dapat dimaknai sebagai sarana atau media pemberdayaan atau muatan life skills. Hal ini dimaksudkan agar tidak terjadi kejenuhan dalam belajar dan diharapkan warga belajar dapat bertahan belajar sampai tuntas dan memperoleh Surat keterangan melek aksara (untuk pendidikan keaksaraan). Sebagai gambaran, walaupun telah diupayakan untuk pengadaan pendidik khususnya tutor kesetaraan dan tutor keaksaraan oleh pemerintah, upaya tersebut belum dapat memenuhi tutor di setiap kelompok belajar. Dari jumlah pengadaan tutor, idealnya setiap ada sepuluh warga belajar keaksaraan memerlukan satu orang tutor, sedangkan untuk pendidikan kesetaraan, dengan perbandingan empat puluh warga belajar membutuhkan satu orang tutor. Oleh karena ketersediaan tutor belum mencukupi jumlah ideal, diperlukan strategi yang cermat dalam kegiatan pembelajaran. Kurang mencukupi dari jumlah ideal tersebut merupakan indikasi adanya pendayagunaan tutor yang tidak efisien disebabkan beberapa faktor, yaitu tutor kurang diminati masyarakat sebagai pilihan profesi dan banyaknya tutor yang menumpuk di perkotaan, tidak menjangkau wilayah kab/kota tertinggal.

Dari hasil kajian lapangan pada saat program PBA (Pemberantasan Buta Aksara) dilaksanakan, ditemui beberapa hambatan sosiokultural di masyarakat dalam upaya pengembangan kompetensi para tenaga pendidik PNF. Apabila dilihat dari makna fleksibilitas penyelenggaraan pembelajaran, sebenarnya sangat tepat mengingat dari sisi waktu, warga belajar serta metode penyampaian materi boleh jadi sangat bergantung pada dinamika masyarakat yang bersangkutan. Setting pembelajaran pada pendidikan nonformal, misalnya keaksaraan dengan warga belajar yang mayoritas adalah perempuan, tidak berpendidikan atau drop out tingkat SD serta dalam usia yang relatif tidak muda lagi, adalah sangat khas. Media belajar yang sederhana bahkan terkesan seadanya adalah kekhasan lain dari proses pembelajaran program pendidikan nonformal.

Seringkali makna fleksibilitas menjadi terlalu longgar bahkan cenderung tidak berpola. Akibatnya, tujuan, target, dan kemanfaatannya menjadi tidak tercapai. Bukan tidak mungkin para tutor mengalami kejenuhan sehingga tugas yang dilakukan pun cenderung tidak optimal. Bagi para tutor, kondisi seperti ini baik secara mandiri maupun kelompok dihadapi dengan melakukan variasi-variasi menurut pemahamannya masing-masing. Adakalanya para tutor ini dengan inisiatif melakukan kegiatan-kegiatan ekstra, misalnya diberikan keterampilan sebagai upaya menarik perhatian warga belajar untuk tetap belajar. 
Pada liputan khusus di Kompas 2 Mei 2007 ditampilkan sebuah sekolah formal pada PKBM penyelenggara kesetaraan kejar Paket B di Jakarta. Makna sekolah formal digunakan untuk menggambarkan penggunaan simbol sekolah formal bagi pembelajaran pada pendidikan nonformal seperti di PKBM.

Meskipun dari sisi waktu diselenggarakan pada sore hari, penggunaan seragam seperti seragam sekolah biasa, pemanfaatan bel sebagai meniru cara sekolah yang menyatakan waktu mulai dan selesainya proses belajar dipandang sebagai sebuah strategi untuk menarik perhatian atau mungkin menjadi motivasi atau image warga belajar terhadap belajar itu sendiri.

Gambaran tersebut di atas barangkali dilakukan oleh tenaga pendidik dan kependidikan nonformal ketika menghadapi kesenjangan antara pemahaman yang dimiliki kondisi lapangan yang dihadapi. Bahan, alat atau kegiatan belajar secara konsep, model atau praktek yang diperoleh tenaga pendidik dan kependidikan PNF melalui pelatihan-pelatihan pengembangan kompetensi tidak dapat diterapkan begitu saja di lapangan.

Pada proses sebelum atau saat pembelajaran berlangsung, pengembangan kompetensi tenaga pendidik pendidikan nonformal juga dihadapkan pada ritual-ritual sosial budaya yang begitu kental melekat pada masyarakat. Kondisi ini juga berpengaruh terhadap fleksibiltas

Tinjauan sosiokultural
yang dihadapi para tenaga
pendidik Pendidikan
Nonformal dapat
digunakan sebagai acuan
para pengambil kebijakan
dan juga menjadi perhatian
Tim Akademisi untuk dapat
memahami kompleksitas
masalah yang dihadapi
para tutor.

untuk hidup lebih berkualitas adalah masalah budaya. Bila sasarannya adalah anak-anak usia sekolah, tidak terlalu sulit mengubahnya. Namun, bila warga belajarnya telah berusia lebih dari 45 tahun dan belum pernah menikmati bangku sekolah (buta huruf murni), tidaklah mudah mengubah paradigma berpikir Pengalaman seorang tutor menghadapi warga belajar yang psikosomatis, belum lagi pembelajaran dimulai, warga belajar tersebut tiba-tiba sakit karena takut tidak bisa mengikuti pembelajaran.

Tinjauan sosiokultural yang dihadapi para tenaga pendidik PNF barangkali dapat digunakan sebagai acuan para pengambil kebijakan dan juga menjadi perhatian Tim Akademisi untuk dapat memahami kompleksitas masalah yang dihadapi para tutor. Kesenjangan juga sering terjadi apabila pengelola atau penyelenggara program atau kegiatan lebih asyik mengurus administrasi keuangan lembaga ketimbang mencoba mema-hami kegiatan yang berlangsung untuk bersama-sama meme-cahkan berbagai persoalan sosiokultural semacam ini. Yang terjadi adalah pengelola atau tenaga kependidikan dengan beban laporan atau pertanggungjawaban kegiatan menjadi kurang peduli atau yang penting proses pembelajaran berjalan sebatas administrasi sebagaimana yang dituntut oleh lembaga di atasnya, misalnya yang bias waktu. Misalnya dengan alasan ritual sosial budaya, waktu penyelenggaraan menjadi tidak pasti bahkan dikorbankan sehingga pembelajaran tidak berjalan secara optimal. Hal lain yang perlu memperoleh perhatian adalah bias gender dan usia terkait dengan value yang lekat dalam diri mereka.

Ketika warga belajar dalam prosesnya mengatakan kulo niki tiyang bodho (saya bodoh), cara berpikir tersebut sudah terinternalisasi selama bertahun-tahun lamanya. Cara berpikir semacam itu mau tidak mau berpengaruh terhadap proses dan keberhasilan mereka dalam belajar. Belum lagi pengalaman masa lalu sebagai perempuan yang merasa diperlakukan beda dengan laki-laki oleh orang tuanya bahwa sekolah itu bukan kebutuhan bagi perempuan, ketika di usianya yang tidak muda lagi harus mengikuti kegiatan belajar, cenderung menghambat peningkatan motivasi warga belajar untuk tuntas buta aksara/huruf. Mengubah paradigma berpikir dari saya bodoh menjadi saya bisa belajar atau belajar itu adalah kebutuhan
Dinas Pendidikan Kota, Kabupaten atau bahkan Pusat. Keadaan-keadaan ini mungkin sudah saatnya untuk diperhatikan secara serius agar tidak semakin rumit, bila perlu tim akademisi yang ditunjuk turut terlibat dalam upaya peningkatan tenaga pendidik dan kependidikan nonformal. Artinya, tim akademisi tidak sekedar mendengar atau mengetahui atas dasar laporan pengelola atau penyelenggara program, namun sekali waktu perlu melihat berlangsungnya proses pembelajaran di masyarakat, serta secara bersamasama melakukan evaluasi untuk mencari solusi dari permasalahan yang ditemukan.

Berbagai strategi yang sistematis untuk mewujudkan PTK-PNF profesional telah pula dilaksanakan dan salah satunya adalah sistem pengembangan profesi. Profesionalisme dan mutu para pendidik nonformal nampaknya ditingkatkan melalui forum komunikasi pendidik dan tenaga kependidikan baik keaksaraan maupun kesetaraan, Pusat Kegiatan Belajar Masyarakat ataupun Ikatan Penilik Indonesia 
dan sebagainya. Forum-forum menjadi rujukan bagi pemerintah pusat maupun daerah dalam mengembangkan kompetensi dan kemampuan PTKPNF secara berkesinambungan. Serangkaian kegiatan pengembangan profesionalisme dan peningkatan mutu pendidik dan tenaga kependidikan nonformal juga dilaksanakan melalui rangkaian kegiatan seminar, forum ilmiah, lomba karya nyata.

Forum Tutor Kesetaraan dan Tutor Keaksaraan telah terbentuk. Namun, jika dinilai dari aspek sinkronisasi dan koordinasi, kualitas koordinasi kurang maksimal. Pada tahun 2006, Direktorat PTK-PNF memfasilitasi sinkronisasi dan konsolidasi program peningkatan mutu PTK-PNF melalui peran asosiasi/ forum PTK-PNF dan secara khusus juga mendampingi penyusunan rencana program kerja tahun 2007. Dengan demikian, diharapkan dalam tahun 2007 telah terjadi peningkatan peran yang diemban oleh asosiasi/forum PTK-PNF.

Persoalannya adalah apakah konsep pengembangan kompetensi melalui berbagai kegiatan termasuk oleh forum PTK-PNF secara sinergis dapat ditindaklanjuti di lapangan, ataukah itu hanya sebagai tanda sudah pernah memperoleh atau ada legitimasi saja dari pelatihan sehingga sah-sah saja bekerja sebagai tenaga pendidik PNF. Pertanyaan tersebut barangkali dapat digunakan sebagai refleksi bagi upaya memaknai kembali profesionalisme atau pengembangan kompetensi tenaga pendidik dan kependidikan nonformal dalam rangka peningkatan mutu pendidikan pada umumnya.

\section{KESIMPULAN}

Dengan memposisikan program pendidikan nonformal sebagai bagian terpadu dan penting dalam Sistem Pendidikan Nasional (Sisdiknas) yang berfungsi mencerdaskan kehidupan bangsa dan mewujudkan kebudayaan nasional, pada hakikatnya kemampuan profesional pendidik dan tenaga kependidikan pendidikan nonformal tidak berbeda dengan pendidik dan tenaga kependidikan pendidikan formal. Perbedaan kedua jalur ini hanya pada karakteristik peserta didik serta model pembelajaran yang dikembangkan. Kemampuan mengorganisasi lembaga pendidikan sejak dari merencanakan, mengembangkan program dan melaksanakan, mengelola hingga mengevaluasi harus dikuasasi oleh pendidik dan tenaga kependidikan itu sendiri.
Keberhasilan pelaksanaan peningkatan profesional PTK-PNF dalam rangka meningkatkan mutu pendidikan secara nasional, juga menjadi harapan nyata bagi pembangunan pendidikan. Peningkatan PTK-PNF dapat dilakukan dengan menggunakan berbagai cara yang disarankan melalui arah, strategi, dan kebijakan Direktorat PTK-PNF. Model yang disarankan memiliki karakteristik tersendiri, demikian juga keadaan PTK-PNF di masing-masing tempat memiliki karakteristik sosiokultural sendiri. Tingkat keberhasilan program peningkatan profesionalisme PTK-PNF sangat bergantung pada pemahaman, kesadaran, keterlibatan, dan upaya sungguh-sungguh dari segenap unsur pelaksana program termasuk di dalamnya optimalisasi Tim Akademisi.

\section{DAFTAR PUSTAKA}

Astuti, P.P. (2007). "Sekolah formal” di PKBM Remaja Masa Depan. Kompas. 2 Mei hal: 40

Baderi, A. (2005). Meningkatkan minat baca masyarakat melalui suatu kelembagaan nasional. Wacana ke arah pembentukan sebuah lembaga nasional pembudayaan masyarakat membaca. Orasi ilmiah dalam pengukuhan Pustakawan Utama.

Direktorat Pendidik dan Tenaga Kependidikan Pendidikan Nonformal. (2007). Membangun profesionalisme dan martabat PTK-PNF. Jakarta 11-14 Agustus. CD.

Jalal, F. (2005). Peranan tenaga pendidik PNF dalam meningkatkan mutu pendidikan melalui jalur pendidikan nonformal. Makalah pada Lomba karya nyata dan karya tulis pamong belajar
Agustus. Jakarta.

Maman, S. (2007). Upaya memantapkan profesionalisme guru. Pikiran Rakyat Cyber Media.

Purwanto. (2002). Meningkatkan profesionalitas guru. Jurnal Teknodik. No.10/VI/ Oktober.

Suryadi, A. (2007). Kebijakan pembangunan pendidikan nonformal. Jakarta: Direktorat Jenderal Pendidikan Luar Sekolah, Departemen Pendidikan Nasional.

Tilaar, H.A.R. (1999). Beberapa agenda reformasi pendidikan nasional: Dalam perspektif abad 21. Magelang: Indonesia Tera.

Waspodo, M \& Aman, S. (2007). Mendongkrak peran strategis PTK-PNF. Misi, Majalah Pendidik PNF. 